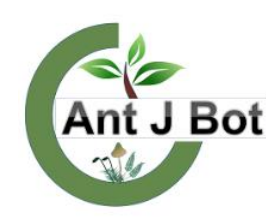

Received :02.02.2021 Accepted :24.03.2021 Online :05.04.2021

\title{
The relationships between environmental and disturbance factors in temperate deciduous forest ecosystem (Amasya/Turkey)
}

\author{
Dudu Duygu KILIÇ ${ }^{1} \odot$, Burak SURMEN ${ }^{2} \oplus^{*}$, Hamdi Güray KUTBAY ${ }^{3} \odot$ \\ ${ }^{1}$ Amasya University, Science and Arts Faculty, Department of Biology, Amasya, Turkey \\ ${ }^{2}$ Karamanoğlu Mehmetbey University, Kamil Özdağ Science Faculty, Department of Biology, Karaman, Turkey \\ ${ }^{3}$ Ondokuz Mayıs University, Science and Arts Faculty, Department of Biology, Samsun, Turkey \\ *buraksurmen@gmail.com,1drduygukilic@gmail.com,3hguray@omu.edu.tr
}

\section{Ilıman yaprak döken ormanlarda (Amasya/Türkiye) tahribat ve çevresel faktörler arasındaki ilişkiler}

\begin{abstract}
Deciduous forests face many disturbance factors. Grazing and cutting are the leading factors in this disturbance. The study area's vegetation was analyzed using numerical methods to identify plant communities and determine the relationship between environmental gradients and disturbance factors. The species diversity was calculated using alpha and beta diversity indexes. As a result, four different communities were identified in the study area. One of the communities was under grazing pressure while the other community was under cutting pressure. No disturbance factors were found in the remaining two communities. Elevation and soil moisture were found to be important in the distribution of plant communities. pH, soil moisture, soil \% N content and canopy factors were found to be important. The highest Shannon-Wienner diversity index values were found in non-cutting and non-grazing forest communities. The lowest Shannon-Wienner diversity index values were found in grazing and cutting forest communities. Unlike the Shannon-Wienner diversity index, the highest beta index values were found in grazing and cutting forest communities. The lowest beta index values were found in non-cutting and non-grazing forest communities.
\end{abstract}

Key words: Plant ecology, plant diversity, numerical method

\begin{abstract}
Özet: Yaprak döken ormanlar birçok tahribat faktörüyle karşı karşıyadır. Özellikle otlatma ve ağaç kesimi bu faktörlerin başında gelmektedir. Çalışma alanının vejetasyonu, bitki komünitelerinin tespiti ve çevresel faktörler ile tahribat faktörleri arasındaki ilişkiyi belirlemek için nümerik metotlar kullanılarak analiz edilmiştir. Tür çeşitililiği alfa ve beta çeşitlilik indeksleri kullanılarak hesaplanmıştır. Sonuç olarak, çalışma alanında 4 farklı komünite tespit edilmiştir. Bu komünitelerden biri otlatma baskısı altındayken diğer komünite ağaç kesimi baskısı altındadır. Diğer komüntelerde ise tahribat faktörleri bulunmamıştır. Rakım ve toprak neminin bitki komünitelerinin dağılımında önemli olduğu bulunmuştur. $\mathrm{pH}$, toprak nemi, toprak $\mathrm{N}$ içeriği ve kanopi faktörleri önemli bulunmuştur. En yüksek Shannon-Wienner indeks değerleri ağaç kesimi ve otlatma olmayan orman komünitelerinde bulunmuştur. En düşük Shannon-Wienner çeşitlilik değerleri ise otlatma ve ağaç kesimi olan orman komüntelerinde bulunmuştur. Shannon-Wienner çeşitlilik indekslerinin aksine, en yüksek beta çeşitlilik indeks değerleri otlatma ve ağaç kesimi olan orman komünitelerinde bulunmuştur. En düşük beta index değerleri ağaç kesimi ve otlatma olmayan orman komünitelerinde bulunmuştur.
\end{abstract}

Anahtar Kelimeler: Bitki ekolojisi, bitki çeşitliliği, numerik metod

Citation: Kılıç DD, Sürmen B, Kutbay HG (2021). The relationships between environmental and disturbance factors in temperate deciduous forest ecosystem (Amasya/Turkey). Anatolian Journal of Botany 5(1): 44-50.

\section{Introduction}

There are significant relationships between plant species and environmental factors in terrestrial ecosystems. Topography, soil characteristics and climatic conditions are determinants factors affecting plant diversity (Davies et al., 2007; Korkmaz et al., 2016). For example, soil pH (Borchsenius et al., 2004; Hofmeister et al., 2009), nutrient availability (Small and McCarthy, 2005; van Calster et al., 2008), soil moisture (Qian et al., 1997, Lenière and Houle, 2006), the mass of litter layer (Gazol and Ibánez, 2009; Kooijman, 2010), light availability (Härdtle et al., 2003; Tinya et al., 2009) and distance to forest edge (Harper et al., 2005; Gonzalez et al., 2010) are among the most critical environmental factors (Vockenhuber et al., 2011).

In temperate deciduous forests, approximately the $90 \%$ of vegetation consists of vascular plant diversity (Whigham, 2004; Gilliam, 2007). The composition and diversity of the ground flora in temperate deciduous forests are affected by the composition of the canopy species and soil and climate characteristics (Hunter, 1999; Augusto et al.,
2003; Gilliam, 2007; Barbier et al., 2008). While underground vegetation contributes significantly to total biodiversity in temperate forests, it contributes less to total forest biomass (Gilliam, 2007).

There are many disturbance factors in temperate forests. Among these, grazing and tree cutting are among the most important. Grazing and tree cutting cause complexity and instability in species interactions (Fakhireh et al., 2012; Hüseyinova et al., 2013; Xu et al., 2016; Kılıç et al., 2018). The intensity of disturbance allows some species to establish, grow, and reproduce (Pierce et al., 2007; Duru et al., 2010; Frenette-Dussault et al., 2012; Kılıç et al., 2018).

In this study, we examined relationships among disturbance (grazing and tree cutting), environment factors (soil $\mathrm{pH}$, soil nitrogen, soil moisture and light availability) and biodiversity in the temperate deciduous forest.

\section{Materials and Method}

The study area is located in the Yeşilirmak basin in the central region of Turkey. The study area is located 
between $400 \mathrm{~m}$ and $1100 \mathrm{~m}$ in altitude (Fig. 1). The study area has between oceanic and continental climates. The mean annual temperature and the mean annual precipitation are $13.9^{\circ} \mathrm{C}$ and $397.5 \mathrm{~mm}$, respectively. The maximum mean temperature is $31.7^{\circ} \mathrm{C}$ (August), while the lowest mean temperature is $-0.6{ }^{\circ} \mathrm{C}$ (January). The vegetation consists of Irano-Turanian and Mediterranean species. Natural flora has been affected by grazing and tree cutting.

Taxonomic nomenclature followed was that of Davis (1965-1985) and Davis et al. (1988), Tutin and Heywood (1964-1980), Güner et al. (2000) and Güner et al. (2012). Four plots were selected from floristically and structurally homogeneous places according to the goal of study. Ten relevés was established for each plot, and the size of plots was determined according to the minimal area method (Westhoff and van Der Maarel, 1978). A cover-abundance value for each species in each relevés was determined using the Braun-Blanquet (1964) scale.

Soil samples for each relevés were taken at a depth of 35 $\mathrm{cm}$. Soil $\mathrm{pH}$ values were measured using deionized water (1:1) by $\mathrm{pH}$ meter (Kacar, 2012). Soil nitrogen was determined by the way of micro-Kjeldahl method (Bradstreet, 1954). Water content was determined by the gravimetric method (Bayrakli, 1987, Kutbay and Ok, 2003). Light availability was determined using a Lutron Light Meter LX-1102 (Schuster and Diekmann, 2005).

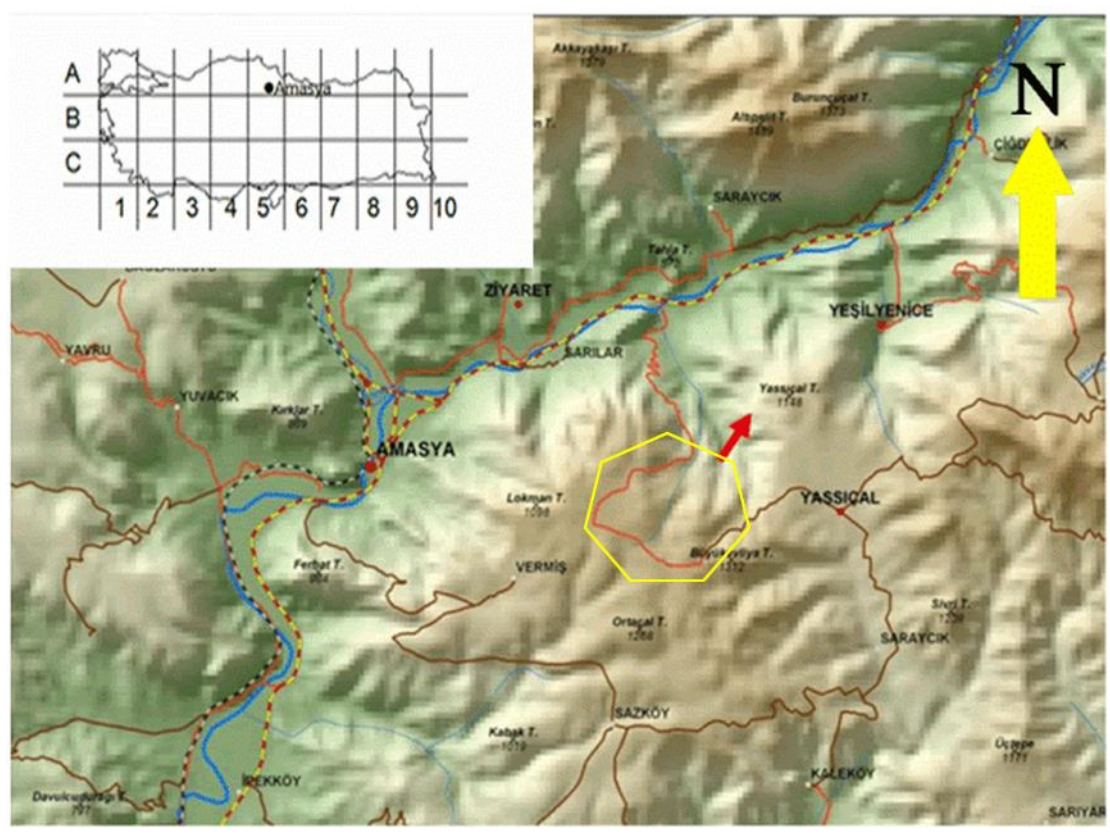

Figure 1. Map of the study area

The Shannon - Wienner diversity indices of the plant communities were calculated using the following formula (Magurran, 2004).

$$
H=\sum_{i=1}^{s} p i x \ln p i
$$

"s" is the total number of recorded species, "pi" is the proportion of percentage cover of the "i"th species to the sum of the percentage cover of all species and $\ln$ is the natural logarithm.

Evenness was quantified using Shannon's indices. Indices of the plant communities were calculated using the following formula (Magurran, 2004).

$$
J=H^{\prime} / H \max
$$

where Hmax is maximum species diversity and calculated as $\log _{2} \mathrm{Pi}$.

Beta diversity is defined as spatial heterogeneity or pattern diversity was calculated using the Whittaker formula (Whittaker, 1960; Gulsoy and Ozkan, 2008).

$$
\beta=\mathrm{S} / \alpha-1
$$

where $\mathrm{S}$ is the total number of species, $\alpha$ is the mean species richness.
Plant communities according to disturbance factors were separated by using TWINSPAN procedure. To determine what environmental factors were significant, we also treated our data with Detrended Correspondence Analysis (DCA) and Principal Component Analysis (PCA). Numerical methods were performed by using the "Community Analysis Package 4 version" software (Seaby and Henderson, 2007).

Statistical analysis was performed by using a SPSS (25.0 version) software. The differences among plant communities were investigated by one-way ANOVA. The biodiversity parameters were assessed by Tukey's significant difference (HSD) test to rank the means.

\section{Results}

TWINSPAN analysis revealed four plant communities. They are grazing, non-grazing, cutting and non-cutting plant communities. Diagnostic species of the grazed area are Acantholimon acerosum (Willd.) Boiss. var. acerosum, Achillea setacea Waldst. et Kit, Carduus pycnocephalus L. subsp. albidus (Bieb.) Kazmi, Globularia trichosantha Fisch, and Juniperus foetidissima Wild., while the ungrazed areas are characterized by Avena sterilis L., Calepina irregularis (Asso) Thell., Capsella bursapastoris (L.) Medik., Hordeum vulgare L., Taraxacum officinale (L.) Weber ex F.H.Wigg., and Urtica dioica L. 
diagnostic species. Diagnostic species of tree cutting areas are Cerasus mahaleb (L.) Miller var. mahaleb (L.) Miller, Cistus creticus L., Colutea arborescens L, Cruciata taurica (Pallas ex Willd.) Ehrend, Jasminum fruticans L., Pistacia terebinthus L. subsp. palaestina (Boiss.) Engler, Polygala pruinosa Boiss. subsp. pruinosa Boiss., and
Vicia narbonensis L., while uncutted areas are characterized by Amelanchier rotundifolia (Lam). Dum.Courset, Arbutus andrachne L., Globularia trichosantha Fisch, Juniperus oxycedrus L. subsp. oxycedrus, Phillyrea latifolia L., Quercus hartwissiana Steven, and Q. petraea (Mattuschka) Liebl. diagnostic species (Fig. 2).

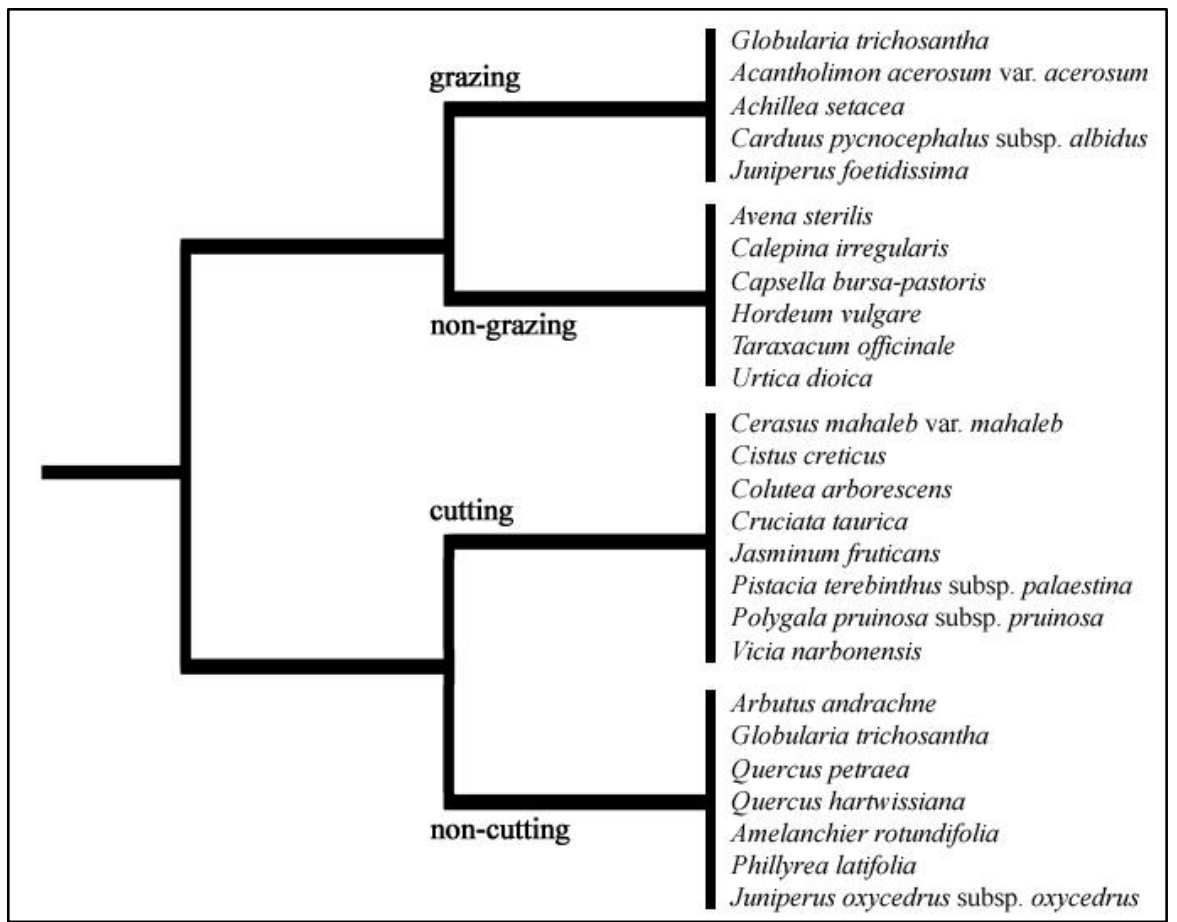

Figure 2. Plant communities considering disturbance factors in the study area resulting from the TWINSPAN analysis.

Detrended correspondence analysis (DCA) diagram showed the existence of the gradient considering the first axis (Eigenvalue of axis 1 is 0.96). It is an elevation gradient. Plant communities have spread depending on the elevation. Plant communities in non-grazing and noncutting areas grouped at the left of ordination plot, whereas plant communities in cutting and grazing areas grouped at the right of the ordination plot (Fig. 3).

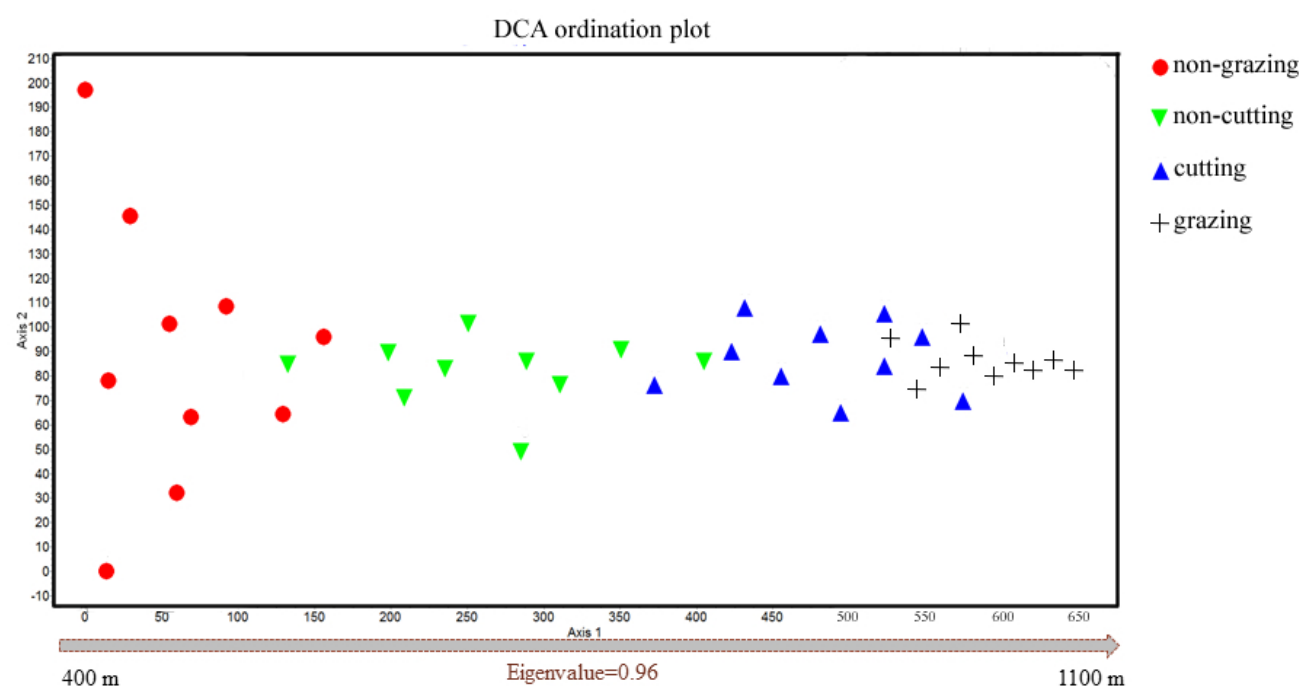

Figure 3. Result of the detrended correspondence analysis (DCA) withthe ordination diagram showing plant communities' position.

The first two axes explained $81.79 \%$ total variance of the Principal Component Analysis (PCA). PCA revealed that $\mathrm{pH}$, soil nitrogen content $(\%)$, soil water content were found to be significant in axis 1 , while light availability was found to be significant in axis 2. Soil nitrogen (\%) and soil water content were negative in axis 1 , while soil $\mathrm{pH}$ and light availability were positive in axis 1 and 2, respectively (Table 1).
Light availability was positively correlated with plant communities in cutting areas, While soil nitrogen content and water content were negatively correlated plant communities in grazing areas. $\mathrm{pH}$ was positively correlated with plant communities in non-grazing areas (Fig. 4). 
Table 1. Eigenvalues for studied environmental factors (Significant values were marked in bold).

\begin{tabular}{lll}
\hline & Axis 1 & Axis 2 \\
\hline Soil pH & $\mathbf{0 . 5 0 8}$ & -0.266 \\
\hline Soil nitrogen content $(\boldsymbol{\%})$ & $\mathbf{- 0 . 5 6 8}$ & -0.450 \\
\hline Soil moisture & $\mathbf{- 0 . 6 4 6}$ & 0.229 \\
\hline Light availability & 0.033 & $\mathbf{0 . 8 2 0}$ \\
\hline
\end{tabular}

Species diversity indices ( $\mathrm{H}$ and $\mathrm{J}$ ) were high in noncutting and non-grazing plant communities compared to the other areas. Beta diversity was high in cutting and grazing plant communities as compared to the other areas. Statistically significant differences were found among the beta diversities with respect to plant communities (Table 2).

\section{Discussions}

The effects of environmental and disturbance factors on plant communities in terrestrial ecosystems are significant (Davies et al., 2007; Pausas and Austin, 2001). These factors affect the establishment, growth and reproduction of species (Pierce et al., 2007; Duru et al., 2010; FrenetteDussault et al., 2012). According to TWINSPAN and DCA analysis, we found the main four plant communities: grazing, cutting, non-cutting and non-grazing. These communities are distributed according to altitude. Because topographic factors (altitude, geographical aspect, and slope) are primary factors of vegetation distribution (Mark et al., 2000) and affecting plant diversity (Vujnovic et al., 2002).

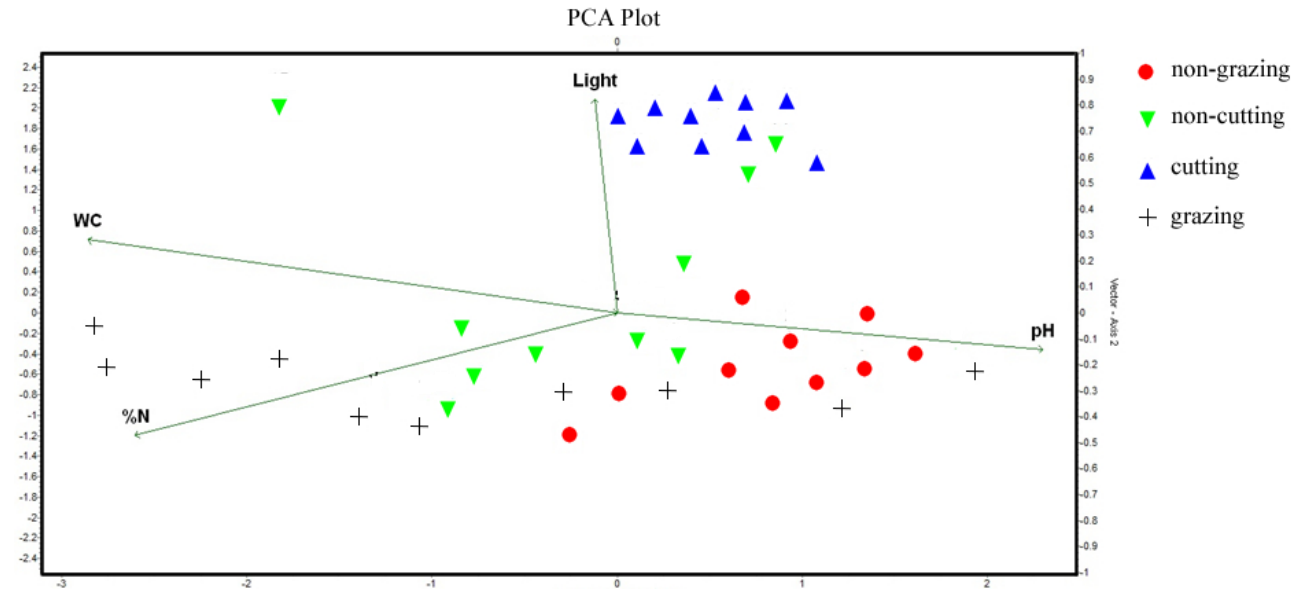

Figure 4. PCA analysis of the among environmental factors and plant communities.

PCA analysis showed that $\mathrm{pH}$, soil nitrogen content (\%), soil water content and $\mathrm{pH}$ were determining factors of vegetation distribution. In the cutting area, light availability is the main determining factor on species composition, while in the non-cutting area, soil $\mathrm{pH}$ and nitrogen content are determining factors (Chai et al., 2016; Tardella et al., 2016). Additionally, unpalatable and thorny species are dominant in grazing vegetation, and fast-growing species are dominant in non-grazing vegetation (Tardella et al., 2016; Kılıç et al., 2018).

Table 2. Diversity indices of plant communities (Different lowercase letters indicate significant differences)

\begin{tabular}{lccccc}
\hline & Grazing & Non cutting & Non grazing & Cutting & Sig. \\
\hline Shannon-Wienner H indice & $0.882 \pm 0.024 \mathbf{a}$ & $0.973 \pm 0.012 \mathbf{a}$ & $0.921 \pm 0.008 \mathbf{a}$ & $0.890 \pm 0.011 \mathbf{a}$ & $0.352 \mathbf{n s}$ \\
\hline Shannon J indice & $1.016 \pm 0.031 \mathbf{a}$ & $1.062 \pm 0.027 \mathbf{a}$ & $1.229 \pm 0.019 \mathbf{a}$ & $1.235 \pm 0.009 \mathbf{a}$ & $0.244 \mathbf{n s}$ \\
\hline $\boldsymbol{\beta}$ indice & $3.481 \pm 0.240 \mathbf{c}$ & $0.367 \pm 0.004 \mathbf{a}$ & $0.215 \pm 0.003 \mathbf{a}$ & $1.137 \pm 0.021 \mathbf{b}$ & $0.022^{*}$ \\
\hline
\end{tabular}

Overgrazing in meadows and pastures damages the ground flora and prevents the regeneration of dominant species (Malik et al., 2016). However, Pettit et al. (1995) stated that overgrazing increases the proportion of unrelated species.

When evaluated results obtained, Shannon-Wienner diversity indexes of grazing vegetation were lower than the other vegetation types (Zhao et al., 2007; García et al., 2009; Tälle et al., 2016; Faria et al., 2018).

It has been found that grazing has a significant effect on species richness and diversity and that the number of species and diversity indexes are lower in these areas ( $\mathrm{Lu}$ et al., 2017; Tälle et al., 2016). Besides, it has been shown that overgrazing negatively affects bush and tree species and thus decreases species richness (Roder et al., 2002; Kumar and Shahabuddin, 2005).

In cutting vegetation, light availability is the main factor (Tardella et al., 2016). Cutting causes permanent grazing gaps, and grassland species are recolonized (Dzwonko and Loster, 1998). These areas are called wood-pastures. If regeneration fails, wood-pastures become permanent. (Bergmeier et al., 2010). In non-cutting vegetation, canopy species have an excellent availability to take light as compared to subcanopy species. Besides, soil $\mathrm{pH}$ and nitrogen content affect ground flora formations (Augusto et al., 2003; Chai et al., 2016).

Species diversity indices ( $\mathrm{H}$ and $\mathrm{J}$ ) were high in noncutting vegetation compared to the cutting vegetation. The ground flora diversity and composition is influenced by the species composition of the canopy species (Barbier et al., 2008; Gilliam, 2007; Hunter, 1999). Beta diversity was higher in cutting and grazing plant communities than the other plant communities.

Overgrazing harms the ground flora in meadows and pastures, preventing the regeneration of dominant species (Malik et al., 2016). Also, the disappearance of shrub and tree species causes the species richness to decrease 
gradually (Roder et al., 2002; Kumar and Shahabuddin, 2005). Considering the results obtained, it was consistent with previous studies (Faria et al., 2018). Tree cutting and forestry studies increase habitat heterogeneity (Bergmeier et al., 2010).

Paying attention to the protection of biological diversity in forestry activities should be the main goal of sustainable forest management. In this study, we revealed that disturbance and environmental factors affect vegetation types and species composition.

\section{Conflict of Interest}

Authors have declared no conflict of interest.

\section{Authors' Contributions}

The authors contributed equally.

\section{References}

Augusto L, Dupouey JL, Ranger J (2003). Effects of tree species on understory vegetation and environmental conditions in temperate forests. Annals of Forest Science 60: 823-831.

Barbier S, Gosselin F, Balandier P (2008). Influence of tree species on understory vegetation diversity and mechanisms involved - a critical review for temperate and boreal forests. Forest Ecology and Management 254: 1-15.

Bayrakli F (1987). Plant and soil analysis. Samsun: OMU Faculty of Agriculture.

Bergmeier E, Petermann J, Schroder E(2010). Geobotanical survey of wood-pasture habitats in Europe: Diversity, threats and conservation. Biodiversity and Conservation 19: 2995-3014.

Borchsenius F, Nielsen PK, Lawesson JE (2004). Vegetation structure and diversity of an ancient temperate deciduous forest in SW Denmark. Plant Ecology 175: 121-135.

Bradstreet RB (1954). Kjeldahl method for organic nitrogen. Analytical Chemistry 26(1): 185-187.

Braun-Blanquet J (1964). Pflanzensoziologie-Grundzüge der vegetationskunde. Springer Verlag, Wien and New York.

Chai Y, Yue M, Wang M, Xu J, Liu X, Zhang R, Wan P (2016) Plant functional traits suggest a change in novel ecological strategies for dominant species in the stages of forest succession. Oecologia 80:771-783.

Davies KW, Bates JD, Miller RF (2007). Environmental and vegetation relationships of the Artemisia tridentata spp. wyomingensis alliance. Journal of Arid Environments 70: 478-494.

Davis PH (1965-1985). Flora of Turkey and the East Aegean Islands, Vol. 1-9. Edinburgh: Edinburgh Univ. Press.

Davis PH, Mill RR, Tan K (1988). Flora of Turkey and the East Aegean Islands, Vol. 10 (Suppl.). Edinburgh: Edinburgh Univ. Press.

Duru M, Ansquer P, Jouany C, Theau JP, Cruz P (2010). Comparison of methods for assessing the impact of different disturbances and nutrient conditions upon functional characteristics of grassland communities. Annals of Botany 106:823831.

Dzwonko Z, Loster S (1998). Dynamics of species richness and composition in a limestone grassland restored after tree cutted. Journal of Vegetation Science 9:387-394.

Fakhireh A, Ajorlo M, Shahryari A (2012). The autecological characteristics of Desmostachya bipinnata in hyper-arid regions. Turkish Journal of Botany 36:690-696.

Faria N, Peco B, Carmona CP (2018). Effects of haying on vegetation communities, taxonomic diversity and sward properties in mediterranean dry grasslands: A preliminary assessment. Agriculture, Ecosystems \& Environment 251: 48-58.

Frenette-Dussault C, Shipley B, Léger JF, Meziane D, Hingrat Y (2012). Functional structure of an arid steppe plant community reveals similarities with Grime's C-S-R theory. Journal of Vegetation Science 23:208-222.

García RR, Jáureguı BM, García U, Osoro K, Celaya R (2009). Effects of livestock breed and grazing pressure on grounddwelling arthropods in Cantabrian heathlands. Ecological Entomology 34(4): 466-475.

Gazol A, Ibánez R (2009). Different response to environmental factors and spatial variables of two attributes (cover and diversity) of the understorey layers. Forest Ecology and Management 258: 1267-1274.

Gilliam FS (2007). The ecological significance of the herbaceous layer in temperate forest ecosystems. Bioscience 57: 845-858.

Gonzalez M, Ladet S, Deconchat M, Cabanettes A, Alard D, Balent G (2010). Relative contribution of edge and interior zones to patch size effect on species richness: an example for woody plants. Forest Ecology and Management 259: 266-274.

Guner A, Aslan S, Ekim T, Vural M, Babaç MT (2012). Türkiye bitkileri listesi (damarlı bitkiler). İstanbul: Flora Araştırmaları Derneği ve Nezahat Gökyiğit Botanik Bahçesi Yayınları.

Guner A, Ozhatay N, Ekim T, Başer KHC (2000). Flora of Turkey and the Aegean Islands, Vol. 11 (Suppl. 2). Edinburgh: Edinburgh Univ. Press.

Gülsoy S, Özkan K (2008). Tür çeşitliliğinin ekolojik açıdan önemi ve kullanılan bazı indisler. Turkish Journal of Forestry 9(1): $168-178$.

Härdtle W, von Oheimb G, Westphal C (2003). The effects of light and soil conditions on the species richness of the ground vegetation of deciduous forests in northern Germany (Schleswig-Holstein). Forest Ecology and Management 182: $327-$ 338.

Harper KA, Macdonald SE, Burton PJ, Chen JQ, Brosofske KD, Saunders SC, Euskirchen ES, Roberts D, Jaiteh MS, Esseen PA (2005). Edge influence on forest structure and composition in fragmented landscapes. Conservation Biology 19: 768-782. 
Hofmeister J, Hosek J, Modry M, Rolecek J (2009). The influence of light and nutrient availability on herb layer species richness in oak-dominated forests in central Bohemia. Plant Ecology 205: 57-75.

Hunter ML (1999). Maintaining biodiversity in forest ecosystems. Cambridge: Cambridge University Press.

Hüseyinova R, Kılınc M, Kutbay HG, Kilıc DD, Bilgin A (2013) The comparison of Grime's strategies of plant taxa in Hac1 Osman Forest and Bafra Fish Lakes in the central Black Sea region of Turkey. Turkish Journal of Botany 37:725-734.

Kacar B (2012). Toprak analizleri, 3rd ed. Ankara: Nobel Ltd.

K1lıç DD, Kutbay HG, Sürmen B, Hüseyinoğlu R (2018). The classification of some plants subjected to disturbance factors (grazing and cutting) based on ecological strategies in Turkey. Rendiconti Lincei. Scienze Fisiche e Naturali 29(1): $87-$ 102.

Kooijman A (2010). Litter quality effects of beech and hornbeam on undergrowth species diversity in Luxembourg forests on limestone and decalcified marl. Journal of Vegetation Science 21: 248-261.

Korkmaz H, Yalcin E, Kutbay HG, Yildirim C (2016). The influence of environmental factors on the distribution and composition of plant communities in Kizilirmak Valley-Black Sea region, Turkey. Revue d'écologie 71(1): 21-34.

Kumar R, Shahabuddin G (2005). Effects of biomass extraction on vegetation structure, diversity and composition of forests in Sariska Tiger Reserve, India. Environmental Conservation 32(3): 248-259.

Kutbay HG, Ok T (2003). Foliar N and P resorption and nutrient levels along an elevational gradient in Juniperus oxycedrus L. subsp. macrocarpa (Sibth. \& Sm.) Ball. Annals of Forest Science 60:449-454.

Leniere A, Houle G (2006). Response of herbaceous plant diversity to reduced structural diversity in maple-dominated (Acer saccharum Marsh.) forests managed for sap extraction. Forest Ecology and Management 231: 94-104.

Lu X, Kelsey KC, Yan Y, Sun J, Wang X, Cheng G, Neff JC (2017). Effects of grazing on ecosystem structure and function of alpine grasslands in Qinghai-Tibetan Plateau: a synthesis. Ecosphere 8(1): e01656.

Magurran AE (2004). Measuring biological diversity. Oxford: Wiley-Blackwell Publishing.

Malik ZA, Pandey R, Bhatt AB (2016). Anthropogenic disturbances and their impact on vegetation in Western Himalaya, India. Journal of Mountain Science 13(1): 69-82.

Mark AF, Dickinson KJ, Hofstde RG (2000). Alpine vegetation, plantdistribution, life form, and environments a humid New Zealandregion. Arctic, Antarctic, and Alpine Research 32:240-254.

Pausas JG, Austın M (2001). Patterns of plant species richness in relation to different environments: An appraisal. Journal of Vegetation Science 12: 153-166.

Pettit NE, Froend RH, Ladd PG (1995). Grazing in remnant woodland vegetation: changes in species composition and life form groups. Journal of Vegetation Science 6(1): 121-130.

Pierce S, Luzzaro A, Caccianiga M, Ceriani RM, Cerabolini B (2007). Disturbance is the principal $\alpha$-scale filter determining niche differentiation, coexistence and biodiversity in an alpine community. Journal of Ecology 95:698-706.

Qian H, Klinka K, Sivak B (1997). Diversity of the understory vascular vegetation in 40 year-old and old-growth forest stands on Vancouver Island, British Columbia. Journal of Vegetation Science 8: 773-780.

Roder W, Gratzer G, Wangdi K (2002). Cattle grazing in the conifer forests of Bhutan. Mountain Research and Development 22(4): 1-7.

Schuster B, Diekmann M (2005). Species richness and environmental correlates in deciduous forests of Northwest Germany. Forest Ecology and Management 206:197-205.

Seaby RM, Henderson PA (2007).Community analysis package (4.1.3). Lymington: Pisces Conservation Ltd.

Small CJ, McCarthy BC (2005). Relationship of understory diversity to soil nitrogen, topographic variation, and stand age in an eastern oak forest, USA. Forest Ecology and Management 217: 229-243.

Tälle M, Deák B, Poschlod P, Valkó O, Westerberg L, Milberg P (2016). Grazing vs. mowing: A meta-analysis ofbiodiversity benefits for grassland management. Agriculture, Ecosystems \& Environment 222: 200-212.

Tardella FM, Piermarteri K, Malatesta L, Catorci A (2016). Environmental gradients and grassland trait variation: insight into the effects of climate change. Acta Oecologica 76:47-60.

Tinya F, Marialigeti S, Kiraly I, Nemeth B, Odor P (2009). The effect of light conditions on herbs, bryophytes and seedlings of temperate mixed forests in $\mathrm{O}^{\prime \prime}$ rseg, Western Hungary. Plant Ecology 204: 69-81.

Tutin TG, Heywood VH (1964-1980). Flora Europaea, Vol. 1-5. Cambridge: Cambridge Univ. Press.

van Calster H, Baeten L, Verheyen K, De Keersmaeker L, Dekeyser S, Rogister JE, Hermy M (2008). Diverging effects of overstorey conversion scenarios on the understorey vegetation in a former coppice-with-standards forest. Forest Ecology and Management 256: 519-528.

Vockenhuber EA, Scherber C, Langenbruch, C, Meißner M, Seidel D, Tscharntke T (2011). Tree diversity and environmental context predict herb species richness and cover in Germany's largest connected deciduous forest. Perspectives in Plant Ecology, Evolution and Systematics 13(2): 111-119.

Vujnovic K, Wein RW, Dale MRT (2002). Predicting plant species diversity in response to disturbance magnitude in grassland remnants of central Alberta. Canadian Journal of Botany 80: 504-511.

Westhoff V, Van Der Maarel E (1978). The Braun-Blanquet approach. In Classification of plant communities (pp. 287-399). Dordrecht: Springer. 
Whigham DE (2004). Ecology of woodland herbs in temperate deciduous forests. Annual Review of Ecology, Evolution, and Systematics 35: 583-621.

Whittaker RH (1960). Vegetation of the Siskiyou Mountains, Oregon and California. Ecological Monographs 30:279-338.

Xu F, Li M, Zhou D, Liu X, Wang R, Guo W (2016). The response of wetland plant communities to disturbance: alleviation through symmetric disturbance and facilitation. Polish Journal of Ecology 64:327-338.

Zhao WY, Li JL, Qi JG (2007). Changes in vegetation diversity and structure in response to heavy grazing pressure in the northern Tianshan Mountains, China. Journal of Arid Environments 68(3): 465-479. 